\title{
Water Governance in Tanzania: Performance of Governance Structures and Institutions
}

\author{
Samwel J. Kabote*, Pius John \\ Department of Development Studies, Sokoine University of Agriculture, Morogoro, Tanzania \\ *Corresponding author: sjkabote@suanet.ac.tz
}

\begin{abstract}
Water governance is becoming imperative because of increasing water shortage for different uses in the world. However, the concept is not explored sufficiently in developing countries like Tanzania. This paper examines water governance in the lines of governance structures and institutions in the Southern Agricultural Growth Corridor of Tanzania. The paper adopted descriptive cross-sectional research design to make sense of the existing situation. Data were collected using quantitative and qualitative methods. A sample size of 270 water users was involved in the survey. Focus group discussions and key informant interviews were used to collect qualitative data. Quantitative data were summarized using SPSS while qualitative data were subjected to content analysis. The results showed presence of weak water governance structures and institutions that cannot influence water users' behaviour. The basin level was unable to control and monitor water quality because of lacking human resource and adequate funding. The formal and informal institutions were interlinked in their operations. However, village governments and village water committees were unable to resolve water conflicts because of being colluded by those who breached the rules. Therefore, concerted efforts are needed to build capacity of the governance structures to enforce institutions in governing water resource.
\end{abstract}

Keywords: water, governance, structures, institutions, Tanzania

Cite This Article: Samwel J. Kabote, and Pius John, "Water Governance in Tanzania: Performance of Governance Structures and Institutions." World Journal of Social Sciences and Humanities, vol. 3, no. 1 (2017): 15-25. doi: 10.12691/wjssh-3-1-3.

\section{Introduction}

Water is one of the critical natural resources for life. Without water there is no life. As such, the demand for water resource is increasing worldwide because of competing uses including domestic use, irrigated agriculture, livestock, wildlife, hydroelectric power generation, recreation, fishing and environmental maintenance. In addition, an increasing population contributes to an increased water demand and use of other natural resources [5]. According to the National Water Policy of 2002, water for domestic use is given highest priority in Tanzania compared to other uses. However, water scarcity is rampant particularly in rural areas. As such, the country has various development aspirations elaborated in the national documents including the Tanzania Development Vision that aspires to supply safe water to the majority, reduce poverty and transform the country's economy into a middle income country by 2025 . Therefore, the country has strategically prioritized a number of production sectors in geographical regions with plenty water and potential for investment. One of those areas is the Southern Agricultural Growth Corridor of Tanzania [14]. Yet, water governance is not explored effectively in the corridor.

The Southern Agricultural Growth Corridor of Tanzania (SAGCOT) was internationally launched in
2011. It covers nearly one-third of the mainland Tanzania including Dar es Salaam, Coastal Region, Morogoro, Mbeya, Iringa, Rukwa and Katavi regions. The river basins covered are Rufiji, Wami/Ruvu and Lake Rukwa. The main objective of the SAGCOT is to improve agricultural productivity, food security and livelihoods in general through multi-stakeholders approach. In addition, Tanzania has a water policy and Acts in place that are not implemented adequately to the extent that the SAGCOT goal may not be realized if water governance is not taken seriously. This paper is organized into four major sections. Section one introduces the paper by stating the research gap. It also reviews literature on governance in general and water governance in particularly. Section two elaborates the methodology used. The paper presents and discusses the results in section three, and finally, the paper provides conclusions and recommendations in section four.

\subsection{Concept of Governance}

A universal definition of governance hardly exists in the literature [17]. Some scholars view the concept in the lines of financial accountability and administrative efficiency. Others take it as a political issue encompassing democracy, human rights and participatory processes. For instance, scholars including Tortajada $[6,15]$ contend that governance is a complex process of making, implementing or not implementing decisions made that considers multi- 
level participation including the public, private sector, civil society and the society in general. Others including UNDP [16] and Rogers and Hall [12] refer to economic, political and administrative authority to manage country's affairs at all levels.

Available literature leads to an argument that there is confusion in terms of defining and measuring governance. Scholars, policy makers and development actors including the International Fund for Agricultural Development (IFAD) [8] have gone further to talking about good governance. They concur on the principles of good governance that include: transparency, accountability, consensus oriented, equity and inclusiveness, participation, rule of law, responsiveness and effectiveness and efficiency. Theoretically, it is difficult to achieve good governance in totality. However, governments must exercise principles of good governance to realize sustainable development. This can be done through intentional planning in terms of policy, legal and political frameworks. When the governing system does not fulfill good governance principles, stakeholders talk of "poor governance' [12]. Water governance improves water security albeit using different mechanisms, processes, approaches and methodological considerations [2]. This implies that one can solve water insecurity problems in developing countries by improving water governance.

Like governance in general, different writers use the concept of water governance differently. For instance, the Global Water Partnership [7], Araral and Wang [2] define water governance as a range of political, social, economic and administrative systems that are in place to develop and manage water resources, and the delivery of water services at different levels of society. Other definitions stress on principles like equity and efficiency in water resources and service allocation and distribution [12,15]. These definitions, among others, do not uncover clear indicators to measure water governance. In other words, available definitions are unclear, capturing many things including policy, economics, finance, politics, regulations and management.

In this paper, principally, water governance is taken as one concerned with how governance structures operate and how institutions influence decisions made by policy makers and implementers to practically manage water resources. Governance structures, in this work, refer to district councils, village governments, water users associations, natural resources committees, village water committees, private sector and civil society. They are the ones concerned with formulation or implementation of water policies, and by-laws. To that effect, the concept of water governance is taken, in this work, as one that involves governance structures and how they are involved in formulation and implementation of policies and by-laws focusing on formal and informal arrangements.

In some developing countries, water governance systems, in terms of legislative framework, function effectively, but not in others. For instance, Ghana has effective legislative framework, while Tanzania, Kenya, Uganda, Niger, Burkina Faso and Benin portray too much activities that are not effective in water rights allocation. In addition, legislations for water conflict resolution are effective in Niger and Ghana, but not in Tanzania, Burkina Faso and Benin. Furthermore, water quality legislations are effective in Benin and Burkina Faso, but not in Tanzania, Kenya, Uganda, Niger, and Ghana [7,15].

Effective water governance is vital for practical water resources management during this period when water scarcity is exacerbated by climate change and other factors. According to Tortajada [15] effective water governance can be achieved through interventions including treating water as an economic good, making water a state property, creating water rights, introducing implementable water laws and policies, establishing effective participatory structures and processes and managing water at a basin level.

Some scholars including Rogers and Hall [12] describe approaches for effective water governance to include 'openness and transparency'. On this, governance structures should work openly and transparently in financial transactions and use an understandable language to the public. On 'inclusive and communicative' approach, the authors emphasize stakeholders' participation throughout the process from policy formulation to implementation, in addition to direct communication with stakeholders. Other things to consider include coherence policies and equitable opportunities for men and women in improving well-being. The authors also argue that effectiveness of water governance depends on 'performance and operation'. On this, authors emphasize on clear defined roles in the legislative and executive processes, clear objectives and implementation of policies and rules and efficiency maximization. According to the Organization for Economic Co-operation and Development (OECD) [10,11] effectiveness of water governance can be measured by using indicators including: (i) input indicators in which one has to report on the existence of legal or regulatory framework and resources in place to enforce its implementation. (ii) process indicators that measure actions in place to reach targeted objectives and (iii) outcome indicators to measure results of good water governance. These indicators are employed in this paper as a model that guides the discussions around water governance structures and institutions in the context of Tanzania.

\subsection{Water Governance in Tanzania}

Water resources in Tanzania include rivers, lakes, wetlands, springs, reservoirs and groundwater aquifers; and many water bodies that are shared with neighbouring countries. The water resource is managed at a basin, catchment, sub-catchment and village levels. The country is divided into river basins including: Pangani, Wami/Ruvu, Rufiji, Ruvuma and Southern Coast, all of which drain into the Indian Ocean, Lake Nyasa, Lake Rukwa, Lake Tanganyika, Lake Victoria and the Internal drainage basins of Lake Eyasi, Manyara and Bubu depression. The Rufiji River Basin is the largest of all covering 177,420 square kilometers. Like in other African countries, water governance in Tanzania is a mix of formal and informal institutions. Informal institutions evolve through continuous interactions and practices normally in response to prevailing situations. These are interlocked in the existing customs, traditions, norms and beliefs. Normally, informal institutions dominate at a grassroots level, but at times they are interdependent with formal institutions that dominate at the basin level. Sokile 
et al. [13] conclude that formal and informal institutions are essential for water governance and they are strictly inseparable. However, the two are uncoordinated resulting into duplication of interventions and possibly unable to govern water resources effectively.

Tanzania has a National Water Policy that was formulated in 1991 and reviewed in 2002 to accommodate global level development changes. The policy aims at a comprehensive framework for sustainable development and management of water resources in the country [20]. This can be achieved through effective legal and institutional framework implemented in a multistakeholders approach rather than emphasizing that the government is the sole investor, implementer and manager of the water resource in rural and urban areas, as used to be in the period between 1967 and 1970s. The National Water Policy shows a clear link between water resources, livelihood security and poverty reduction by focusing on three key areas: (i) water resources management (ii) rural water supply and (iii) urban water supply and sewerage. The policy not only emphasizes community participation of water users in managing water, but also partnership with NGOs, private sector, and other actors. However, the commitment of the private sector and civil society is overestimated in the policy indicating that the policy is fundamentally flawed [4]. While the policy stresses on community participation of water users in managing water, it hardly points out the specific roles of informal institutions and structures. This situation renders informal institutions and structures not only with a subordinated role of water governance but also subject to interpretational relevance and extent of application relative to formal institutions. The policy only mentions community participation in terms of sensitization, community education, consultation and discussions in relation to policy implementation for water management [20]. Therefore, it suffices to argue that from these participatory limitations of the community, the current policy creates a policy-legal lacuna as to what extent and how informal institutions should work parallel to the formal institutions and structures that are well stated in the policy document.

The National Water Policy shows that water scarcity is becoming a serious problem in the country even in areas that had no problems in the past. This is caused by a number of factors including prolonged and severe drought, competing uses of water resource, and degradation of water sources and catchments. This is categorically posing worries in food security, energy production and environmental integrity. The policy also reveals that there are inadequate regulations to monitor groundwater resources development causing water underutilization and or over utilization in some areas. The efforts, in Tanzania, to provide safe water to the human population can be seen in the Tanzania Development Vision (TDV) 2025 that stresses universal access to safe water in urban areas and $90 \%$ coverage in rural areas. The efforts are also seen through development and implementation of the water sector development programme (2006-2025), water resource management Act No. 11 of 2009 and the water supply and sanitation Act No. 12 of 2009 [20]. Table 1 summarizes water policy trends in Tanzania over different historical development since colonial period to date.
The Poverty and Human Development Report [21] puts clear that water supply services in rural areas in Tanzania increased by $7.5 \%$ from $40.4 \%$ between 2007 and 2010 . In addition, water supply increased marginally by $1.6 \%$ from $57.1 \%$ between 2007 and 2009 and declined by $0.9 \%$ from $58.7 \%$ between 2009 and 2010 largely because of drought. In urban areas, access to safe and clean water increased marginally by $1.2 \%$ from $80 \%$ between 2007 and 2010 . It is worth noting that the indicator used to measure access to safe drinking water is normally a proportion of human population using an improved drinking water source. An improved water source is defined as one that by nature of its construction or through active intervention is protected from outside contamination. According to the African Ministers' Council on Water (AMCOW) [1], improved drinking water sources include: Piped water, standpipe, borehole, protected dug well, protected spring and rain water. It is clear that the foregoing statistics enlighten that the trends in access to safe and clean water in rural areas are not consistent. Available data also shows that majority in urban areas have access to safe and clean water compared to rural areas in the country. This implies that water problems affect rural than urban areas, and therefore water governance is inescapable to address water related concerns especially in rural areas. The next sections of this paper elaborate the methodology, present the results and discussion, conclusions and recommendations.

\section{Methodology}

The study was conducted within the Southern Agricultural Growth Corridor of Tanzania (SAGCOT) in Sumbawanga cluster, in Rukwa and Katavi regions, and covered Sumbawanga, Kalambo and Nkasi districts in Rukwa and Mpanda Districts in Katavi Regions. The districts were selected because human population is increasing rapidly due to a good climatic condition for crop production and livestock keeping relative to other parts in the country. Animal population is also increasing rapidly because of immigration of pastoralists and therefore jeopardizing water sources and management. Four landscapes were involved in the survey as shown in Table 2. A landscape is defined, in this paper, as an area of a countryside or land of a particular type, used especially when talking about its appearance. The targeted population were households because they are one of the main water users in the corridor. The study adopted descriptive cross-sectional research design to collect quantitative and qualitative data at the same time and at one point in time. The questionnaire was the main data collection tool and it was used to collect type of data focusing on relationship between variables. Both closedended and open-ended questions were used.

\subsection{Sampling and Sample Size}

The survey involved 9 villages. The choice of villages was informed by availability of water sources, availability of small scale irrigation schemes, and proximity to a Lake especially Lake Rukwa and Tanganyika. Information about villages involved in the study is presented in Table 3 . A combination of simple random sampling and systematic 
sampling techniques were used to select representative households involved in the survey. Sampling frames were prepared in each village by listing all households. The total sample size was 270 households, 30 from each village. The study interviewed heads of household or any adult person at a household, a man or woman. Quantitative data were collected using survey method whereas qualitative data were collected using key informant interviews with Local Government Authorities (LGAs) and Water Basin Offices (WBOs). One FGD in each village was conducted to collect information on governance structures and water institutions. Information on villages involved and the size of FGDs are shown in Table 3 and Table 4. Qualitative data focused on capacity to monitor and manage water quality at different levels, formal and informal institutions governing water and land resources management, mechanisms, procedures and capacity to resolve water resource conflict. A checklist of items was used to guide qualitative data collection. Gender dimension consideration was substantial during selection of FGDs participants because different gender groups have different interests on water resource. To that effect, it was essential to capture information from men and women.

Table 1. Water policy trends in Tanzania

\begin{tabular}{|c|c|c|c|}
\hline Colonial period (1890s-1961) & High modernist period (1967-1970s) & Transition period (1980s) & $\begin{array}{l}\text { Liberalization period (end of } \\
1990 \mathrm{~s}-2000 \mathrm{~s})\end{array}$ \\
\hline $\begin{array}{l}\text { Reliance on improvement of } \\
\text { indigenous systems and there } \\
\text { were some large scale } \\
\text { irrigation projects }\end{array}$ & $\begin{array}{l}\text { - Water taken as a public good } \\
\text { - High state's capital investment on the } \\
\text { water sector } \\
\text { - Access to improved water sources } \\
\text { increased from } 12 \% \text { to } 46 \% \\
\text { - High levels of donor funding } \\
\text { - Lack of community participation in } \\
\text { design and management of water projects }\end{array}$ & $\begin{array}{l}\text { - The state and the donor } \\
\text { offered water services } \\
\text { together } \\
\text { - Access to improved water } \\
\text { sources stood at } 46 \%\end{array}$ & $\begin{array}{l}\text { - The period of polycentric } \\
\text { governance } \\
\text { - Private sector, civil society and } \\
\text { communities offering services } \\
\text { - The state as a facilitator and } \\
\text { regulator } \\
\text { - Access to protected water sources } \\
\text { increased to } 55 \%\end{array}$ \\
\hline
\end{tabular}

Source: [4].

Table 2. Landscapes involved in the survey

\begin{tabular}{|c|c|c|c|c|}
\hline $\mathbf{S} / \mathbf{N}$ & Name of landscape & Characteristics & District & Region \\
\hline 1 & Sumbawanga - Mtowisa & $\begin{array}{l}\text {-High deforestation rate for farming and competition for water resource by } \\
\text { the up and down stream users }\end{array}$ & Sumbawanga & Rukwa \\
\hline 2 & Kassanga - Matai & -Fast growing population and heavy deforestation for charcoal making & Kalambo & Rukwa \\
\hline 3 & Mwese - Mwamankulu - Sitalike & $\begin{array}{l}\text {-Deforestation } \\
\text {-Land degradation and unsustainable water resource management }\end{array}$ & Mpanda & Katavi \\
\hline 4 & Kate - Chala & $\begin{array}{l}\text {-Influx of large herds of cattle creating land conflicts } \\
\text {-Unsustainable natural resource management }\end{array}$ & Nkasi & Rukwa \\
\hline
\end{tabular}

Table 3. Village information

\begin{tabular}{|c|c|c|c|c|c|}
\hline Village name & Landscape & Men population & Women Population & Total Number of Households & Sample Selected \\
\hline Mtowisa A & Sumbawanga - Mtiwisa & 2,010 & 3,030 & 1,006 & 30 \\
\hline Ng'ongo & Sumbawanga - Mtiwisa & 1381 & 1446 & 626 & 30 \\
\hline Wipanga & Sumbawanga - Mtiwisa & 1264 & 1219 & 420 & 30 \\
\hline Kafukoka & Kassanga-Matai & 708 & 915 & 393 & 30 \\
\hline Kassanga & Kassanga-Matai & 1327 & 1953 & 1300 & 30 \\
\hline China & Kate-Chala & 1037 & 1095 & 442 & 30 \\
\hline Chala C & Kate-Chala & 1031 & 1004 & 224 & 30 \\
\hline Katuma & Mwese - Mwamankulu - Sitalike & 3484 & 3540 & 1258 & 30 \\
\hline Mwamankulu & Mwese - Mwamankulu - Sitalike & 1327 & 1953 & 980 & 30 \\
\hline \multicolumn{5}{|l|}{ Total } & 270 \\
\hline
\end{tabular}

Table 4. Characteristics of focus group discussions' participants

\begin{tabular}{|c|c|c|c|c|c|c|}
\hline Village name & Men & Women & FGD size & Mean age (years) & Minimum age (years) & Maximum age (years) \\
\hline Mtowisa A & 8 & 2 & 10 & 40 & 30 & 51 \\
\hline Ng'ongo & 5 & 2 & 7 & 36 & 24 & 48 \\
\hline Wipanga & 3 & 3 & 6 & 44 & 43 & 46 \\
\hline Kafukoka & 6 & 3 & 9 & 40 & 24 & 56 \\
\hline Kassanga & 4 & 6 & 10 & 48 & 32 & 64 \\
\hline China & 4 & 2 & 6 & 62 & 39 & 86 \\
\hline Chala C & 6 & 3 & 9 & 37 & 28 & 46 \\
\hline Katuma & 5 & 5 & 10 & 48 & 35 & 62 \\
\hline Mwamankulu & 6 & 1 & 7 & 61 & 42 & 80 \\
\hline
\end{tabular}




\subsection{Data Analysis}

Quantitative data analysis involved coding, data entry using Statistical Package for Social Sciences (SPSS), data cleaning, verification and analysis. Descriptive statistics and cross tabulations were computed to show an existing situation and relationships between different variables in the landscapes. Tables are used to present the results. Qualitative data analysis involved summarizing of field notes based on the objectives of the study. The analysis also involved content analysis.

\section{Respondents' Characteristics}

Table 5 presents respondents' characteristics.

The analysis in Table 5 shows that $78.1 \%$ of the respondents were heads of households. The rest were spouses, daughters, sons and other relatives. This implies that the survey involved the targeted people, the household heads. The high percentage of the household heads is attributed to timing of the survey that was conducted in May 2016. This period, in the study area, is the time when households have finished farming activities awaiting for harvesting. Therefore, most of the heads of household were available at home. The analyses also showed that $83.7 \%$ of the heads of household were males. This reflects an African and in particular a Tanzanian situation in which the household head is normally a man. Further observations showed that $78.5 \%$ of the respondents were married. This can be explained by the fact that the nature of socio-economic activities in rural areas, which is mainly agriculture, requires intensive labour force. Spouses normally perform most of the farming activities in rural Tanzania and are treated as labour producers [9]. The same Table shows that $80.4 \%$ of the respondents had primary education level, followed by ordinary secondary education. Education is a key variable for social development. Having respondents with primary education level implies that they were able to count and write and possibly to do simple numeric calculations in addition to simple reasoning related to water governance.

Table 5. Respondents' characteristics

\begin{tabular}{|c|c|c|c|c|c|}
\hline Variable & $\begin{array}{l}\text { Sumbawanga-Mtowisa } \\
(\mathrm{n}=90)\end{array}$ & $\begin{array}{l}\text { Kasanga- } \\
\text { Matai(n=60) }\end{array}$ & $\begin{array}{l}\text { Mwese-Mwamankulu- } \\
\text { Sitalike(n=60) }\end{array}$ & $\begin{array}{l}\text { Kate-Chala } \\
(\mathrm{n}=60)\end{array}$ & Total $(\mathbf{N}=\mathbf{2 7 0})$ \\
\hline \multicolumn{6}{|c|}{ Relationship with household head } \\
\hline Head of the household & 26.3 & 16.7 & 19.3 & 15.9 & 78.1 \\
\hline Spouse & 5.9 & 4.8 & 2.2 & 5.9 & 18.9 \\
\hline Daughter/Son & 0.7 & 0.4 & 0.7 & 0.7 & 2.6 \\
\hline Other relatives & 0.4 & 0.0 & 0.0 & 0.0 & 0.4 \\
\hline Total & & & & & 100 \\
\hline \multicolumn{6}{|l|}{ Respondents' sex } \\
\hline Male & 26.3 & 19.6 & 18.1 & 19.6 & 83.7 \\
\hline Female & 7.0 & 2.2 & 4.1 & 3.0 & 16.3 \\
\hline Total & & & & & 100 \\
\hline \multicolumn{6}{|l|}{ Respondents' marital status } \\
\hline Married & 25.2 & 18.9 & 15.9 & 18.5 & 78.5 \\
\hline Never Married & 2.6 & 1.1 & 2.2 & 1.1 & 7.0 \\
\hline Divorced/Separated & 2.6 & 0.7 & 2.6 & 1.1 & 7.0 \\
\hline Widower & 0.4 & 0.4 & 0.4 & 0.4 & 1.5 \\
\hline Widow & 2.6 & 0.7 & 1.1 & 1.5 & 5.9 \\
\hline Total & & & & & 100 \\
\hline \multicolumn{6}{|c|}{ Education Level of the respondents } \\
\hline No formal education & 3.7 & 0.4 & 1.1 & 1.5 & 6.7 \\
\hline Primary & 25.2 & 19.3 & 19.3 & 16.7 & 80.4 \\
\hline Ordinary Secondary & 4.1 & 2.2 & 1.5 & 3.7 & 11.5 \\
\hline Advanced secondary & 0.0 & 0.0 & 0.4 & 0.0 & 0.4 \\
\hline Vocational training & 0.0 & 0.0 & 0.0 & 0.4 & 0.4 \\
\hline College & 0.4 & 0.0 & 0.0 & 0.4 & 0.7 \\
\hline Total & & & & & 100 \\
\hline \multicolumn{6}{|c|}{ Respondents' major occupation } \\
\hline Agriculture & 32.6 & 16.7 & 19.6 & 21.9 & 90.7 \\
\hline SME Entrepreneur & 0.0 & 0.7 & 1.5 & 0.4 & 2.6 \\
\hline Natural resources extraction & 0.0 & 0.4 & 0.0 & 0.0 & 0.4 \\
\hline Civil servant & 0.4 & 0.0 & 1.1 & 0.4 & 1.9 \\
\hline Charcoal burning & 0.4 & 0.0 & 0.0 & 0.0 & 0.4 \\
\hline Fishing & 0.0 & 4.1 & 0.0 & 0.0 & 4.1 \\
\hline Total & & & & & 100 \\
\hline
\end{tabular}


The living of $91 \%$ of the respondents depended on agriculture, and this was their major occupation, followed by fishing, and Small and Medium Enterprises (SMEs) (Table 5). Water resource is critical for farming and fishing activities, among others such that the study on water governance was relevant to the majority of respondents. Civil servants in the sample were mainly teachers, nurses and agricultural extension officers, possibly because the study was conducted in rural areas. Sumbawanga-Mtowisa had the highest number of farmers followed by Kate-Chala. The dependence on agriculture reported, in this study, is higher than $66.9 \%$ of employment that agriculture provides at a national level [22]. Other socio-economic activities include livestock keeping, fishing, and small-scale business. Agriculture is mainly rain-fed in the study area. Irrigated agriculture, though is critical for agricultural productivity, is limited and it is taking place in a few isolated traditional irrigation schemes observed at $\mathrm{Ng}$ 'ongo and Mwamankulu villages.

\section{Results and Discussion}

\subsection{Water Sources for Domestic Use}

Table 6 shows water sources for domestic use in the four landscapes involved in the study area. The results show that $47.8 \%$ of the respondents depended on improved sources especially standpipe while $46.3 \%$ depended on unprotected sources mainly springs, rivers, Chaco-dam, lake and shallow wells. This implies that water sources were diverse. Water from natural springs and river sources were reported throughout the landscapes particularly at Sumbawanga-Mtowisa and Kasanga-Matai landscapes. Qualitative results also revealed rivers and natural springs as among the major water sources that required attention in terms of governance. To ensure sustainability, and with increasing water demand due to population increase, the issue of water governance has become critical so that the water sources serve not only the present generation, but also the next generations. In Africa, 64\% of the people use improved drinking water sources [18]. This figure is higher than the $47.8 \%$ reported in this paper possibly because the study focused in rural areas, which are normally marginalized in the country not only in access to water but also other social services.

\subsection{Governance Structures}

Water governance structures were examined through FGDs and key informant interviews. The results uncovered a number of governance structures including Lake Rukwa Basin, Village Water Committees formed by Village Governments, Water Users Associations (WUAs), District Councils and Community Water Use Supply Organizations (COWSOs). Since water governance issues need collaboration with other sectors, water governance structures are expected to work together with different committees including environment, land and forest in ensuring an effective water governance system. These were reported during FGDs and were responsible for formulation and implementation of by-laws to govern water resource.
Qualitative data also showed that the Lake Rukwa Basin is mandated for monitoring of water quality in the study area, and it had water laboratory in Sumbawanga town. Another laboratory is located in Mbeya City. During FGDs, participants reported that the Lake Rukwa Basin Water Office located in Mbeya City had one laboratory technician. The laboratory lacked reagents to test heavy metals like mercury $(\mathrm{Hg})$ and lead $(\mathrm{Pb})$. The office had one engineer, 2 hydrologists and 2 hydrogeologists. In addition, the office reported challenges in terms of fund and deficit of one staff for each of the mentioned professionals. This implies that the capacity of the basin to govern water resources in terms of controlling water quality was weak. Based on the results and following ineffective water quality legislations at the national level in Tanzania, water governance in terms of water quality was undeniably not effective. This is a common phenomenon in many African countries including Kenya, Uganda, Niger, Burkina Faso and Benin $[7,15]$.

Water Users Associations (WUAs) and Community Water Use Supply Organizations (COWSOs) were reported in some villages. For instance, FGDs reported one WUA at Mwamankulu and Mtowisa villages. These organizations were responsible for water resource management at a village level. In Kasanga-Matai landscape, water governance structures were missing except water department under the district council. There was one water engineer implying weak water governance and resources management. At Mwese-MwamankuluSitalike, there was, in addition to the district council, Water Users Associations (WUAs) responsible for implementation of by-laws for water management. Village Water Committees in each village responsible for all issues related to water governance were reported throughout the study villages (Table 7). Generally, women involvement in the water committees was outstanding, and this is critical because women are responsible to collect domestic water in most of the African societies including Tanzania [9]. Even though, FGDs reported that the water committees were unable to resolve water conflicts between water users, and in some villages the committees were completely dormant, suggesting poor governance. Therefore, interventions to revive them and build their capacities to resolve water conflicts are imperative.

It is important to note that one cannot govern water resources in isolation to the management of other natural resources including land, forest and the environment in general. Putting differently, water governance is likely to be ineffective if planning and management of the mentioned resources including water itself is fragmented and uncoordinated. In other words, to achieve meaningful water governance, efforts should involve management of water sources that are directly linked to the land, forest and the physical environment in general. Table 8 presents awareness of the respondents' responses about presence of governance structures in different sectors and sub-sectors of the economy that are necessary for water governance.

\subsection{Formal Water Institutions}

Table 9 presents existence of formal institutions in the study area. Formal institutions in this study include water 
by-laws and policies that influence behaviour of water users. The results showed that $47.4 \%$ of the respondents reported existence of water by-laws or regulations implemented by the village water committees in collaboration with the village governments to practically manage water resource. This implies that the institutions were in place and were operating. Water governance structures were expected to implement those institutions to ensure improved water governance. Qualitative results were in agreement with quantitative results. For instance, FGDs at Kafukoka village reported that:

'...we have by-laws implemented by the village government that govern water by restricting cutting trees, grazing animals and farming activities within 60 metres from the river banks or a water source...'
That quotation justifies presence of formal institutions. However, $40 \%$ of the respondents (Table 9) did not report existence of formal institutions implying that they were unaware about their existence possibly because the institutions were not able to influence water users' behaviour. About $23 \%$ of the respondents were aware of the National Water Policy. It also featured out, during FGDs, that some participants were not aware of the presence of water policy. Being not aware has implications in terms of water use, governance and management because the institutions are expected to influence water users and managers' behaviour in using the resource. Unawareness of the policy, by-laws or regulations is likely to aggravate water resources degradation and therefore affecting water quality, availability and management.

Table 6. Major water sources

\begin{tabular}{|c|c|c|c|c|c|}
\hline Households' sources of water & $\begin{array}{l}\text { Sumbawanga- } \\
\text { Mtowisa (n=90) }\end{array}$ & $\begin{array}{c}\text { Kasanga-Matai } \\
(\mathrm{n}=60)\end{array}$ & $\begin{array}{l}\text { Mwese-Mwamankulu- } \\
\text { Sitalike (n=60) }\end{array}$ & $\begin{array}{c}\text { Kate-Chala } \\
(\mathrm{n}=60)\end{array}$ & Total $(N)=270$ \\
\hline Piped Water & 10.7 & 10.4 & 0.4 & 3.3 & 24.8 \\
\hline Public tap/stand pipe & 19.6 & 11.1 & 6.3 & 10.7 & 47.8 \\
\hline Protected well & 0.0 & 0.0 & 0.0 & 2.2 & 2.2 \\
\hline Unprotected well & 0.4 & 0.7 & 6.3 & 4.1 & 11.5 \\
\hline Rain water collection & 0.7 & 0.0 & 0.4 & 0.7 & 1.9 \\
\hline Chaco dam & 0.0 & 0.4 & 0.4 & 0.4 & 1.1 \\
\hline Protected well & 0.0 & 2.2 & 1.1 & 0.0 & 3.3 \\
\hline Unprotected spring/river & 16.3 & 8.9 & 14.1 & 7.0 & 46.3 \\
\hline Lake & 0.4 & 0.0 & 0.0 & 0.0 & 0.4 \\
\hline Shallow well & 0.0 & 0.0 & 0.4 & 0.0 & 0.4 \\
\hline
\end{tabular}

NB: Percentages in the last column do not add up to 100 because of multiple responses.

Table 7. Membership in village water committees

\begin{tabular}{|l|c|c|c|c|}
\hline Village name & Men & Women & Total & \% of women \\
\hline Mtowisa A & 5 & 5 & 10 & 50.0 \\
\hline Ng'ongo & 4 & 2 & 6 & 33.3 \\
\hline Wipanga & 3 & 3 & 6 & 50.0 \\
\hline Kafukoka & 4 & 4 & 8 & 50.0 \\
\hline Kassanga & 4 & 4 & 5 & 50.0 \\
\hline China & 2 & 3 & 6 & 60.0 \\
\hline Chala C & 3 & 3 & 8 & 50.0 \\
\hline Katuma & 6 & 2 & 6 & 25.0 \\
\hline Mwamankulu & 5 & 1 & & 16.6 \\
\hline
\end{tabular}

Table 8. Existing governance structures

\begin{tabular}{|c|c|c|c|c|c|}
\hline Response & $\begin{array}{c}\text { Sumbawanga-Mtowisa } \\
(\mathrm{n}=90)\end{array}$ & $\begin{array}{c}\text { Kasanga-Matai } \\
(\mathrm{n}=59)\end{array}$ & $\begin{array}{l}\text { Mwese-Mwamankulu- } \\
\text { Sitalike }(\mathrm{n}=60)\end{array}$ & $\begin{array}{c}\text { Kate-Chala } \\
(\mathrm{n}=61)\end{array}$ & Total $(n=270)$ \\
\hline Village land committee & 23.7 & 16.3 & 19.6 & 20.0 & 79.6 \\
\hline Village forest committee & 15.2 & 10.7 & 12.2 & 10.0 & 48.1 \\
\hline $\begin{array}{l}\text { Village natural resource } \\
\text { management committee }\end{array}$ & 20.0 & 16.3 & 15.2 & 19.6 & 71.1 \\
\hline Village water resource committee & 12.6 & 10.7 & 12.6 & 9.3 & 45.2 \\
\hline Village fisheries committee & 1.1 & 3.3 & 0.0 & 0.0 & 4.4 \\
\hline Not aware & 2.6 & 1.1 & 0.7 & 0.0 & 4.4 \\
\hline Environmental committee & 2.2 & 0.0 & 0.0 & 0.0 & 2.2 \\
\hline
\end{tabular}

NB: Percentages in the last column do not add up to 100 because of multiple responses. 
Table 9. Respondents' responses on formal institutions in percentages

\begin{tabular}{|c|c|c|c|c|c|}
\hline Water legal framework & $\begin{array}{c}\text { Sumbawanga-Mtowisa } \\
(\mathrm{n}=90)\end{array}$ & $\begin{array}{c}\text { Kasanga-Matai } \\
(n=60)\end{array}$ & $\begin{array}{c}\text { Mwese-Mwamankulu- } \\
\text { Sitalike }(n=60)\end{array}$ & $\begin{array}{l}\text { Kate-Chala } \\
\quad(n=60)\end{array}$ & $\begin{array}{c}\text { Total } \\
(\mathbf{N})=270\end{array}$ \\
\hline National Water Policy & 8.9 & 3.3 & 5.9 & 4.4 & 22.6 \\
\hline Water resource management Act & 4.4 & 2.2 & 2.2 & 3.7 & 12.6 \\
\hline None of the above & 13.7 & 11.1 & 6.3 & 8.9 & 40.0 \\
\hline Total & & & & & 100 \\
\hline
\end{tabular}

NB: Percentages in the last column do not add up to 100 because of multiple responses.

Based on the National Water Policy of Tanzania and Water Resources Management Act of 2009, water resources management system in the country is governed by the Water Utilization (Control and Regulation) Act No. 42 of 1974 and its subsequent amendments Act No. 10 of 1981 that introduced pollution control aspects. The management also includes the Minister of water responsible for national policy and strategy formulation, the director of water resources who provides advisory services to the government in all issues related to water resources. Other governance structures include the National Water Board, Basin Water Boards and catchments and sub-catchments water committees. However, the Water Utilization Act and other sub-sector related laws are inadequate to meet the growing water governance challenges facing the country today at a local level [20]. This implies that concerted efforts are needed to build capacity regarding water governance at a local level.

\subsection{Informal Water Institutions}

Informal institutions include cultural norms, values, customs, beliefs and traditions governing individuals' behaviour in society regarding water use. Table 10 and Table 11 present informal institutions governing water resources. The results show that $64.8 \%$ of the respondents did not report cultural norms for water governance implying that, although informal institutions were available, majority of the respondents were not aware about their presence (Table 10). The rest reported that cultural norms in water governance were practiced.

It is clear from Table 10 that responses of the respondents who reported presence of cultural norms for water governance were in line with qualitative results. For instance, FGDs at Chala village reported that:

'...we have a norm in this village that strictly prohibits anyone to cut a tree in the water sources...otherwise one can disappear completely...'

The norm in that quotation is by far strong, likely to be respected by all community members, and therefore helpful in water governance. Cultural norms have, for many years, been practiced in the study area for protection of ecosystems including water sources, and these have had proved effective. However, participants during FGDs reported that some of the cultural practices presented in Table 11 had disappeared, weakened or transformed into statutory by-laws promoted by the local governments in the study area. This being the case, as argued in the preceding sections, the National Water Policy can be partly blamed for failures to provide a clear direction that stipulates the roles of informal institutions. In order to achieve maximum community involvement, the policy governing water management would be expected to clearly stipulate and strategize the roles of informal institutions and structures instead of underestimating them. Notably, synthesis from FGDs showed that when different people with different traditions and norms mix together in a village, some traditions, beliefs and customs become diluted and slowly diffuse and weaken in the community and may slowly disappear. A case in point is Rukwa and Katavi regions (study regions) where immigration of pastoralists brought new ethnic groups and therefore causing conflicting of different beliefs, cultural norms and traditions. Some of the customs, traditions and norms reported to be practiced across the landscape include restricting farming activities near water sources or on some of the areas identified for rituals (Table 11). Others were prohibiting cutting trees near water sources and elders banning grazing or setting bush fires near water sources. These were informal such that they were not documented, overseen by the elders, but known and respected throughout the communities. As such, they were potential for water governance.

Based on the FGDs, it is clear that breaching informal institutions could make gods angry and therefore punishing the one who breached the norms. Sometimes, the whole society could be punished by, for instance, having long periods of droughts. The effects could be shortage of drinking water, shortage of water for livestock and poor agricultural productivity, and these could negatively affect livelihoods in general. Some of the informal rules, for instance, restricting farming activities near water sources, are also promoted and enforced by the local government by-laws. This implies that informal institutions were interlinked with formal institutions. In other words, the two were inseparable and it is good that they worked concurrently to strengthen water governance. Literature however shows that formal and informal water institutions in Tanzania are uncoordinated in their functions resulting into duplication of interventions [13]. Therefore, concerted initiatives at a policy level are needed for the two to work together effectively.

Table 10. Use of norms and cultural practices governing water resource in \%

\begin{tabular}{|l|c|c|c|c|}
\hline Response & $\begin{array}{c}\text { Sumbawanga-Mtowisa } \\
(\mathbf{n = 9 0 )}\end{array}$ & $\begin{array}{c}\text { Kasanga-Matai } \\
(\mathbf{n = 6 0 )}\end{array}$ & $\begin{array}{c}\text { Mwese-Mwamankulu- } \\
\text { Sitalike (n=60) }\end{array}$ & Kate-Chala (n=60) \\
\hline Yes & 8.9 & 7.8 & 8.5 & 10.0 \\
\hline No & 24.4 & 14.1 & 13.7 & 12.6 \\
\hline Total & \multicolumn{4}{|c|}{$\mathbf{1 0 0}$} \\
\hline
\end{tabular}


Table 11. Percentage respondents' responses on norms and cultural practices

\begin{tabular}{|c|c|c|c|c|c|}
\hline Response & $\begin{array}{c}\text { Sumbawanga- } \\
\text { Mtowisa (24) } \\
\end{array}$ & $\begin{array}{l}\text { Kasanga- } \\
\text { Matai (21) } \\
\end{array}$ & $\begin{array}{c}\text { Mwese-Mwamankulu- } \\
\text { Sitalike (23) } \\
\end{array}$ & $\begin{array}{c}\text { Kate-Chala } \\
(27) \\
\end{array}$ & $\begin{array}{c}\text { Total } \\
(\mathrm{N}=95) \\
\end{array}$ \\
\hline Restricted areas for rituals and traditional practices & 20.0 & 15.8 & 16.8 & 15.8 & 68.4 \\
\hline Prohibited to cut trees near water sources & 3.2 & 1.1 & 5.3 & 5.3 & 14.7 \\
\hline $\begin{array}{l}\text { Growing banana trees and gardens around water } \\
\text { resources }\end{array}$ & 0.0 & 4.2 & 0.0 & 1.1 & 5.3 \\
\hline Not applicable & 1.1 & 0.0 & 1.1 & 1.1 & 3.2 \\
\hline $\begin{array}{l}\text { Elders have banned grazing and bush fire around } \\
\text { water sources }\end{array}$ & 0.0 & 0.0 & 1.1 & 5.3 & 6.3 \\
\hline Not allowed to construct houses near water sources & 1.1 & 1.1 & 0.0 & 0.0 & 2.1 \\
\hline Total & & & & & 100 \\
\hline
\end{tabular}

\subsection{Water Conflicts and Management}

Table 12 presents respondents' responses on water conflicts over different periods of time. Overall, the results show that $50.7 \%$ of the respondents did not report water conflicts. The rest reported to have been involved in water conflicts at one point in time. A few reported to have been involved in the conflict more than five years ago. Combining those who were involved in the water conflict during the year of data collection of this study, in 2016, with those who reported conflict in one to two years ago, it makes $43.3 \%$ (Table 12). This implies that the trends in occurrence of water conflicts were increasing. Water conflicts were caused by a number of factors, but the prominent one was water scarcity reported by $54.9 \%$ of the respondents (Table 13). Basically, water conflict is caused, not by lack of water, but by a poor way water resource is governed and managed [19]. Specifically, weak policies and by-laws; and inadequate administrative capacity lead to water resource conflict among the users at a local level. To that effect, combating water related conflicts requires strengthening of water governance structures, policies and by-laws that influence water users' behaviour to govern and manage the resource.

Water conflicts involved different actors including farmer with another farmer, or with immigrant pastoralists and to a lesser extent with investors as reported in KateChala. Table 14 presents different actors involved in water conflicts. Qualitative results revealed a number of governance structures involved in water conflict resolution including Katuma River Basin Association, village governments, ward tribunals and traditional soldiers known as sungusungu. FGDs at Mwamankulu village noted low capacity of village governments to resolve water related conflicts. They reported that:

'...the village government is unable to assist in controlling those who breach the rules through farming, grazing animals or cutting trees within water sources...when called to the village government those who breach the rules do not come...'

The information in the quotation above shows that the village government was weak in resolving water conflicts. Synthesis in FGDs also showed that the village governments were colluded by those who breached the rules making them not effective. This largely explains why those who breached the rules were not responding positively to the call made by the village governments. To that effect, the village governments had low capacity to resolve water conflicts. In addition, being colluded suggests that they practiced 'poor governance'.

Table 12. Respondents reporting water conflicts in percentages

\begin{tabular}{|c|c|c|c|c|c|}
\hline Period of time of conflict & $\begin{array}{l}\text { Sumbawanga- } \\
\text { Mtowisa }(n=90)\end{array}$ & $\begin{array}{l}\text { Kasanga-Matai } \\
\quad(n=60\end{array}$ & $\begin{array}{c}\text { Mwese-Mwamankulu- } \\
\text { Sitalike }(n=60\end{array}$ & $\begin{array}{l}\text { Kate-Chala } \\
\quad(n=60)\end{array}$ & Total $(n=270)$ \\
\hline Did not experience & 45.6 & 67.8 & 53.3 & 39.3 & 50.7 \\
\hline This year & 21.1 & 5.1 & 35.0 & 29.5 & 22.6 \\
\hline One to Two years ago & 32.2 & 11.9 & 10.0 & 23.0 & 20.7 \\
\hline Three to five years ago & 1.1 & 11.9 & 1.7 & 8.2 & 5.2 \\
\hline More than five years ago & 0.0 & 3.4 & 0.0 & 0.0 & 0.7 \\
\hline Total & 100.0 & 100.0 & 100.0 & 100.0 & 100.0 \\
\hline
\end{tabular}

Table 13. Respondents' responses on major cause of water conflicts in percentages

\begin{tabular}{|c|c|c|c|c|c|}
\hline Factor for Conflict & $\begin{array}{l}\text { Sumbawanga- } \\
\text { Mtowisa }(n=49)\end{array}$ & $\begin{array}{c}\text { Kasanga-Matai } \\
(n=19)\end{array}$ & $\begin{array}{l}\text { Mwese-Mwamankulu- } \\
\text { Sitalike }(n=28)\end{array}$ & $\begin{array}{l}\text { Kate-Chala } \\
\quad(n=37)\end{array}$ & Total $(n=133)$ \\
\hline Unequal water allocation & 20.4 & 21.1 & 14.3 & 8.1 & 15.8 \\
\hline Water Price & 0.0 & 5.3 & 0.0 & 0.0 & 0.8 \\
\hline Destruction of water resources & 14.3 & 5.3 & 7.1 & 21.6 & 13.5 \\
\hline Total & 100.0 & 100.0 & 100.0 & 100.0 & 100.0 \\
\hline
\end{tabular}


Table 14. Respondents' responses on actors involved in water conflicts in \%

\begin{tabular}{|c|c|c|c|c|c|}
\hline Type of actor & $\begin{array}{c}\text { Sumbawanga- } \\
\text { Mtowisa }(n=49)\end{array}$ & $\begin{array}{c}\text { Kasanga-Matai } \\
(n=19)\end{array}$ & $\begin{array}{c}\text { Mwese-Mwamankulu- } \\
\text { Sitalike }(n=28)\end{array}$ & $\begin{array}{c}\text { Kate-Chala } \\
(n=37)\end{array}$ & Total $(n=133)$ \\
\hline Neighbor & 69.4 & 94.7 & 82.1 & 73.0 & 76.7 \\
\hline Authority responsible for water allocation & 2.0 & 0.0 & 0.0 & 0.0 & 0.8 \\
\hline Pastoralist & 2.0 & 0.0 & 7.1 & 2.7 & 3.0 \\
\hline Immigrants pastoralist & 4.1 & 0.0 & 7.1 & 13.5 & 6.8 \\
\hline Investor/s & 0.0 & 0.0 & 0.0 & 8.1 & 2.3 \\
\hline Farmers from the neighboring village & 6.1 & 0.0 & 3.6 & 0.0 & 3.0 \\
\hline Upstream farmers versus low lands & 16.3 & 5.3 & 0.0 & 2.7 & 7.5 \\
\hline Total & 100.0 & 100.0 & 100.0 & 100.0 & 100.0 \\
\hline
\end{tabular}

\section{Conclusions and Policy Recommendations}

The paper discussed governance structures and institutions for governing water resource in the Southern Agricultural Growth Corridor of Tanzania in Sumbawanga cluster. Based on the results, the paper concludes that the major water sources were standpipe, natural springs and rivers. The governance structures involved were basin boards, village water committees, village government, water users associations and district councils. The capacity of the water basin to monitor water quality was weak. In some places, village water committees were dormant and in places where they were working, their capacity to resolve water conflicts was weak. This calls for the government's concerted efforts to build capacity of the water basin to monitor and control water quality. The government should also make the funding and human resource available regarding water quality control. It is also imperative that the capacity of the village water committees and village governments to resolve water conflicts is built and strengthened. The paper also concludes that both informal and formal institutions to govern water resource existed. Nevertheless, the institutions did not influence behaviour of some water users who were not aware about them. Informal institutions were very strong and had proved effectiveness. To that effect, they should be promoted in line with formal institutions and their roles and synergies with formal institutions be formally stipulated in the National Water Policy; after all, the two were interlinked in their functions. In addition, awareness creation on the institutions is critical to enhance water governance.

\section{Acknowledgements}

The study did not benefit any external source of funding. However, authors acknowledge support, during data collection, from village governments and water users.

\section{Competing Interests}

The authors have no competing interests.

\section{References}

[1] African Ministers' Council on Water (AMCOW) (2008). A Snapshot of Drinking Water in Africa. Prepared for AMCOW as a
Contribution to the $11^{\text {th }}$ Summit of Heads of State and Governments of the African Union with Special theme: Meeting the Millennium Development Goals on Water and Sanitation 30 June to 1 July, 2008.

[2] Araral, E and Wang, Y. (2013). Water Governance 2.0: A Review and Second Generation Research Agenda. Water Resources Management 27 (11): 3945-3957.

[3] Araral, E and Yu, D. J. (2013). Comparative law, policies, and administration in Asia: evidence from 17 countries. Water Resources Research, 49: 5307-5316.

[4] Cleaver, F and Toner, A. (2006). The evolution of community water governance in Uchira, Tanzania: the implication for equality of access, sustainability and effectiveness. Natural Resources Forum, 30: 207-218.

[5] Franks, T., Lankford, B and Mdemu, M. (2004). Managing water amongst competing uses: the Usangu wetland in Tanzania. Irrigation and Drainage, 53: 1-10.

[6] Fukuyama, F. (2013). What is Governance? Accessed on 22 November 2016 at https://fsi.fsi.stanford.edu/sites/default/files/What_Is_Governance _v3.pdf.

[7] Global Water Partnership (2006). Effective Water Governance in West and East Africa Synthesis Report. Prepared for Program for Effective Water Governance (EU-supported), MetaMeta/ Overseas Development Institute. 30pp.

[8] International Fund for Agricultural Development (IFAD) (1999). Good Governance: an Overview. Accessed on 22 November 2016 at

http://www.ipa.government.bg/sites/default/files/pregleddobro_upravlenie.pdf

[9] Kabote, S.J., Nombo, C.I., Urassa, J.K., Mattee, A.Z., Mamiro, D.P and Masolwa, L.M (2016). Gender responsive adaptation to climate change in semi-arid environments of Tanzania is achievable. EPINAV policy brief No. 01/2016. Sokoine University of Agriculture, Morogoro.

[10] Organization for Economic Co-operation and Development (OECD) (2015a). Water Governance Indicators: World Water Forum, Korea 15 April, 2015.

[11] Organization for Economic Co-operation and Development (OECD). (2015b). Inventory of Water Governance Indicators and Measurement Frameworks. Accessed on 24/01/2017 at http://www.riob.org/IMG/pdf/Inventory_Indicators-5.pdf.

[12] Rogers, P and Hall, A. W. (2003). Effective Water Governance. Global Water Partnership Technical Committee No. 7. Sweden.

[13] Sokile, C.S., Mwaruvanda, W and Koppen, B. (2005). Integrated Water Resource Management in Tanzania: Interface between Formal and Informal Institutions. A Paper Presented at the International Workshop on 'Africa Water Laws: Plural Legislative Frameworks for Rural Water Management in Africa' Held in Johannesburg South Africa on 26-28 January 2005.

[14] Southern Agricultural Growth Corridor of Tanzania Investment Partnership Program (SAGCOT) (2012). Initiatives to ensure sustainable water supply for communities and investors in the SAGCOT Corridor. Presented by the Minister for Water Hon. Prof. Jumanne Maghembe (MP) to the Tanzania Agribusiness Investment Showcase Event 27 November 2012. Available on 21 November 2016, at http://www.sagcot.com/uploads/media/6._SAGCOT_Showcase_ Min_Water.pdf.

[15] Tortajada, C. (2010). Water governance: some critical issues. International Journal of Water Resources Development, 26 (2): 297-307. 
[16] United Nations Development Programme (UNDP) (1997) Governance for sustainable human development, UNDP policy document, New York.

[17] United Nations Economic and Social Council (2006). Compendium of basic terminology in governance and public administration. United Nations Economic and Social Council. New York.

http://unpan1.un.org/intradoc/groups/public/documents/un/unpan0 22332.pdf. Accessed on 22 November 2016.

[18] United Nations Environmental Programme (UNEP) (2010). Africa Water Atlas. Division of Early Warning and Assessment (DEWA). United Nations Environment Programme (UNEP). Nairobi, Kenya. http://www.unep.org/pdf/africa_water_atlas.pdf accessed on 22/11/2016.
[19] United Nations Environmental Security (2004). Water, Conflicts and Cooperation Policy Brief. Accessed from

https://www.wilsoncenter.org/sites/default/files/ecspr10_unfcaribelko.pdf on 12/01/2017.

[20] United Republic of Tanzania (URT) (2002). National Water Policy. Ministry of Water and Livestock Development. Dar es Salaam.

[21] United Republic of Tanzania (URT) (2011). Poverty and Human Development Report. Research on Poverty Alleviation. Dar es Salaam.

[22] United Republic of Tanzania (URT) (2016). National Five Year Development Plan 2016/17 to 2020/21. Ministry of Finance and Planning. Dar es Salaam. 293pp. 